\title{
Impact of Covid-19 on Teaching and Learning in Africa Assessed by the Education Unions
}

\author{
Steve Nwokeocha ${ }^{1}$ \\ ${ }^{1}$ Africa Federation of Teaching Regulatory Authorities (AFTRA), Abuja, Nigeria \\ Correspondence: Professor Steve Nwokeocha, Africa Federation of Teaching Regulatory Authorities (AFTRA), \\ Abuja, Nigeria. E-mail: drsteve44@gmail.com
}

Received: April 7, 2021 Accepted: May 12, 2021 Online Published: May 19, 2021

doi:10.5539/jel.v10n4p15 URL: https://doi.org/10.5539/jel.v10n4p15

\begin{abstract}
The study investigated the situation and views of the Education International (EI) member unions in Africa regarding the Covid-19 pandemic. The EI, a global body of education unions with over 32.5 million members in 384 unions across 178 countries in the world, is a critical global education stakeholder. It commissioned this study to obtain evidence to inform its policies about the pandemic. The primary data are based on the opinions of union leaders from 58 education unions in 34 African countries who responded to a semi-structured online questionnaire, while additionally, thirteen union leaders across the African countries and the Chief Regional Coordinator of the EI Africa Region were interviewed. The findings revealed a massive disruption of education, exacerbated educational inequalities, teachers' poor digital skills and lack of infrastructure, and increased vulnerability of the marginalized learners shut out of school. Recommendations were made for EI, African Union and Governments.
\end{abstract}

Keywords: Covid-19 impact in Africa, teaching and learning, education unions' responses

\section{Introduction}

The Covid-19 virus was detected in December 2019 in Wuhan, China. By March 2020, it became a global pandemic. In August 2020, there were 23,057,288 individuals infected with the Covid-19 virus at the global level and 800,906 of them died (WHO, 2020). In the same month, there were 1,187,937 Covid-19 cases in Africa with 27,779 deaths and 906,691 recoveries (Africa Centre for Disease Control, CDC, 2020). Yet the cases kept rising, with no vaccine or final cure in sight. The effects of the pandemic on all spheres of life - health, education, economy, politics, and families - have been profound. In education, there has been a massive disruption of schools, together with teaching and learning. In the words of Audrey Azoulay, the UNESCO Director-General, 'while temporary school closures as a result of health and other crises are not new unfortunately, the global scale and speed of the current educational disruption is unparalleled and, if prolonged, could threaten the right to education' (UNESCO Associated Schools Network, 2020, p. 1).

In April, 2020, The World Bank Education Global Practice observed that while the world was already going through a learning crisis, with the Covid-19 pandemic over 160 countries had closed schools affecting about 1.6 billion children and out-of-school youth. It feared that the Covid-19 induced education crisis might cause not only loss in learning but also loss of human capital at the long run. In the same month, April 2020, UNESCO (2020a) cited the figures released by its Institute for Statistics on the impact of the Covid-19 pandemic on the education system. According to the figures, classroom learning is interrupted for 9 out of 10 children worldwide; 191 countries closed their schools at all levels, halting schooling for over 1.5 billion students; and about half of the affected students have no access to online learning while the schools remained closed. The figures, further, revealed that in Sub-Saharan Africa, ' $89 \%$ of learners [216 million] do not have a household computer'; ' $82 \%$ of learners [199 million] do not have household internet'; '26 million learners (or 11\%) are not covered by mobile networks'; and ' $64 \%$ of primary and $50 \%$ of secondary teachers have received minimum training and this frequently does not include basic ICT skills' (UNESCO, 2020a, pp. 1-2). This study was taken against this backdrop to have a better understanding of the realities in Africa, with reference to how the pandemic is affecting the teachers, education support personnel and students. This study was among other steps taken (e.g., Education International, 2020a, 2020b, 2020c, 2020d; Education International Africa Regional Committee, 2020a) by Education International at the global and Africa Regional levels to deal pragmatically with the effects 
of the pandemic on its members. The steps included commissioning research on the impact of the Covid-19 pandemic on teaching and learning at the global level, declaring what it considered as the basic principles to deal with the pandemic, and issuing guidelines for school reopening. In investigating the impact of the Covid-19 pandemic, this study covered the following issues: (1) teaching and learning; (2) social and policy dialogue between the government and education unions; (3) teacher's working conditions; (4) union action; (5) reopening of educational institutions; and (6) expectations of the unions going forward.

\section{Methodology}

The study applied mixed methods - it obtained data using the questionnaire and interview techniques. The researcher designed an online questionnaire using the Google forms application. It was semi-structured, with thirty-three questions requiring 'forced choice', multiple answers, or open responses. The Education International Africa Region validated the questionnaire and thereafter officially circulated the link to the questionnaire to all its member unions in Africa, requesting them to complete the questionnaire within a stipulated timeline in August 2020. At the close of entries, the questionnaire was completed by 54 education unions in 34 countries of Africa.

The countries involved in this study are as follows: Angola, Benin, Botswana, Burkina Faso, Burundi, Cabo Verde, Cameroon, Chad, Comoros, Congo, Cote d'Ivoire, Democratic Republic of Congo, Ethiopia, Gabon, Gambia, Ghana, Kenya, Lesotho, Malawi, Mali, Morocco, Mozambique, Namibia, Niger, Nigeria, Rwanda, Senegal, Sierra Leone, South Africa, Togo, Tunisia, Uganda, Zambia and Zimbabwe. Overall, all the five geographical zones of Africa were included in the study_East, West, North, Southern and Central Africa. Also, although not all the Education International member unions responded, the response rate of 54 out of 120 EI member unions in Africa provided a fair overview of the COVID-19 situation in the continent. The researcher, furthermore, interviewed the Chief Regional Coordinator of Education International Africa Region and thirteen union leaders selected from thirteen countries. The interview complemented the data obtained from the online questionnaire. The literature of several international organizations on how to contain the Covid-19 pandemic in the education system was also reviewed and this proved useful in the discussion of findings.

\section{Results}

\subsection{Teaching and Learning During the Covid-19 Pandemic}

Teaching and learning are the primary business of the education system. They are the core determinants of educational attainments. Therefore, the relevant international organizations (African Union Commission, 2020b; Education International, 2020a; Teacher Task Force \& International Labour Organization, 2020a; UNESCO, 2020c) advocated that that the governments and institutions must ensure the continuity of teaching and learning by online and other means during the pandemic. Thus, the study required the respondents to state whether the schools, from the early childhood education to tertiary education, were open or closed, and the modes and effectiveness of teaching and learning during the pandemic. For early childhood, primary and secondary schools, $43 \%$ of the unions stated that the schools were closed, $8 \%$ indicated that all schools were open, while $49 \%$ stated that schools were open for certain categories of students. Similarly, for tertiary education institutions, $49 \%$ of the unions reported that all the institutions were closed, $15 \%$ indicated that all the institutions were open, and 36\% stated that schools were open for certain categories of students. Therefore, for the majority of the respondents ( $43 \%$ in the case of the lower schools and $49 \%$ for tertiary institutions) all schools were closed; for slightly less than the majority ( $49 \%$ for lower schools and $36 \%$ for tertiary institutions), schools were open only for certain categories of students. Only a small number of respondents (8\% for lower schools and $15 \%$ tertiary institutions) indicated that all schools were open. It could, therefore, be deduced that most of the schools and tertiary education institutions in the African continent were still shut at the time of the survey in August 2020.

With regards to the continuity of teaching and learning for early childhood, primary and secondary education during the pandemic, the commonest measure by the government was getting the students to be taught through the radio and television; $87 \%$ of the respondents chose this option. Next to this was teaching the students through online means, which was ticked by $55 \%$ of the respondents. Other initiatives which had less frequency in Africa were teaching the students through paper-based take-home packages (32\%), that this through work books; and $13 \%$ of the respondents stated that the schools and teachers were also expected to come up with their own initiatives. Only $6 \%$ of the respondents indicated that the government took no action. This means that governments, in the main, tried to ensure the continuity of teaching and learning. In the case of tertiary education, $75 \%$ of the respondents stated that the government encouraged the provision of online tertiary education while $25 \%$ felt that the government took no action. The respondents were further asked to rate the effectiveness of the online or distance education mode adopted during the pandemic for all the levels of education. The majority 
(83\%) opined that the strategy was not effective. Only a minority (17\%) believed that it was effective.

\subsection{Social and Policy Dialogue Between Education Unions and Government}

The study asked the unions whether they were involved by the government in making decisions to manage the impact of the pandemic on education. They were also asked what nature of support (if any) they received from government to ameliorate the impact of the pandemic on their members. The study revealed that only $9 \%$ of the unions were consulted by the government and their views fully taken into account; $11 \%$ indicated they were consulted but their views largely ignored; and majority (51\%) opined they were consulted, and their views sometimes taken into account. The rest (28\%) opined they were not consulted at all. In other words, most of the unions were consulted though the extent to which their opinions were implemented varied. The respondents were also given a checklist of suggested government support to choose from and a majority (62\%) chose the option which stated that "no measures have been taken." However, $28 \%$ of the respondents indicated that they had received support from the government in terms of training and professional development during the period of the pandemic. They were also given a column in the online questionnaire to report any other form of support, if not included in the checklist, and most of the respondents did not indicate any other form of support from government other than the categories stated.

\subsection{Teacher Working Conditions}

The study examined the effects of the pandemic on the payment of salaries and conditions of service of the teachers as well as the rate of Covid-19 infection among them. Those most affected by either cut, delay or termination in the payment of salaries and employment contracts were the full-time teachers on temporary contracts $(49 \%)$ and part-time teachers on temporary contracts $(47 \%)$. The rest were moderately affected as follows: full-time teachers on permanent contracts $(28 \%)$, part-time teachers on permanent contracts (19\%), education support staff $(25 \%)$, and other category of education workers $(26 \%)$. The respondents were asked if there were cases of students and their members infected by the Covid-19 virus. A majority (52\%) answered "Yes" while the rest (48\%) answered "No". Those who answered in the affirmative were asked to provide the exact figures of infected persons, but they indicated that the figures were not available. The few that provided figures were South Africa (4123 cases with 50 deaths); Ghana (310); Mali (25 teachers and 100 students); Namibia (22 teachers); Comoros (cumulative positive 399; active cases 23; cured 379 and dead 7); Zimbabwe (50 students and teachers); and Benin (40). Some respondents, however, provided a reason for their inability to provide the figure, and this had to do mainly with the way the government and health authorities confidentially handled the identity of those infected.

\subsection{Union Action}

The study sought to know the actions taken by the unions to support teaching and learning and to assist their members to handle the effects of the pandemic. The two most outstanding actions taken by the unions were raising of awareness among members (92\%) and engaging in social and policy dialogue with the government $(72 \%)$. The third action was developing tools for members (38\%) and just $2 \%$ of the respondents indicated that the union had not taken action. Some respondents interviewed explained further the efforts of the unions. For instance, the South Africa Democratic Teachers Union (SADTU), informed that:

WhatsApp communication tool was created for daily information sharing to defeat the misinformation and fake news. The union also formed branch-regional-national COVID-19 interim Centers for the development of messages. The union further conducted surveys to inform engagements and initiated two collective agreements to deal with comorbidities and substitute teachers. The union then engaged telecommunication companies to give access to online learning materials free of charge so that teachers and learners did not have to pay for the data. (SADTU, South Africa)

Also, the Syndicat Autonome de l'Enseignement Supérieur (SAES), Senegal stated as follows:

We manufactured hydro-alcoholic gel in large quantity in our laboratories and distributed to the people. We also raised funds (up to eleven million CFA) and donated it to the government to help to fight the pandemic. The fund was paid directly to the COVID-19 Fund Committee set up by the government. (SAES, Senegal)

Importantly also, Education International $(2020 \mathrm{~g}, 2020 \mathrm{~h})$ published reports of two education unions which took the government to court and won during the pandemic. According to the report, the Universities Academic Staff Union (UASU) of Kenya took the Vice Chancellors of two public universities to the Employment and Labour Relations Court to challenge cuts in the salaries of 877 lecturers which a judge had previously suspended (Education International, 2020g). Also, Trade unions in Zimbabwe took the government to court over school reopening and won the case (Education International, 2020h). Such cases show that some unions asserted their 
rights while dealing with the pandemic and they succeeded.

\subsection{Reopening of the Educational Institutions}

With respect to the reopening of schools, the study investigated three related issues such as (1) the approach adopted by the governments to reopen the schools, that is, whether the schools were reopened in phases or all at once; (2) opinion of the respondents regarding the right time to reopen the schools; and (3) adequacy of the Covid-19 protocols put in place by the government for reopened or soon-to-reopen schools. A majority (75\%) ticked the option that schools were being reopened starting with the examination (exit) classes, that is, the schools were being reopened in phases. On the adequacy of the Covid-19 protocols, this was rated separately for the early childhood, primary and secondary schools, and tertiary education. The respondents were requested to rate the adequacy of the following indicators on a scale of 1-5: (1) Provision of water for sanitation and washing of hands; (2) Provision of personal protective equipment; (3) Social distancing within and outside the classroom; (4) Provision of the schools with health guidelines; and (5) Ability of the schools to meet the WHO and health guidelines.

For all the levels of education, most of the unions reported that the measures taken by the government were 'inadequate'. For instance, $36 \%$ of the respondents stated that the provision of water for sanitation and washing of hands in the lower schools was 'inadequate' while $28 \%$ stated that it was 'fairly adequate', giving a total of $64 \%$ who rated the adequacy to be 3 or less on a scale of $1-5$. For the tertiary education institutions, $31 \%$ of the respondents stated that the provision of water for sanitation and washing of hands wea 'inadequate' while $21 \%$ stated that it was 'fairly adequate', making for a total of $52 \%$ who rated the adequacy to be 3 or less. The other indicators followed this trend, such that the average rating of all indicators by all the unions was 3 on a scale or $1-5$. Regarding the preferred date for the reopening of schools, $53 \%$ (in the case of the lower schools) and $58 \%$ (in the case of the tertiary education institutions) preferred a future reopening date when the Covid-19 pandemic might have come under control. A slightly less number stated that it was right to open the schools now provided the Covid-19 protocols are put in place. This implies that the unions were evenly divided for and against the reopening of schools now.

\subsection{Fears and Expectations of the Unions Going Forward}

The study asked the respondents to state how online education and educational technologies might affect the future of the teaching profession. Most of them (60\%) opined that they might cause teachers to lose their job. A lesser number (43\%) felt that they will make the job easier. Those who opined that online education and digital technologies may not have much effect for the teaching profession were $26 \%$. The unions were also asked about their overall worries about the impact that the pandemic could have in education. They expressed worry over a wide range of issues. For instance, many respondents stated that the pandemic could widen the educational gap between the rich and poor children, lower the quality of education, and force more children out of school.

Some of the respondents (e.g., Namibian National Teachers Union, Namibia) explained its worry about the vulnerable children who are being left behind in the learning process. According to union, the vulnerable children lacked resources and for some of them, their parents or guardians could not even give them transport money to school to collect the workbooks before the lockdown. These vulnerable children also lost school feeding which they used to enjoy when the schools were open, which means that many of them might be going through hunger. According to the union, even the children of the well-to-do parents in the urban areas also lost a valuable amount of learning while out of school; when their parents go to work, they are left without adequate supervision of their learning at home. In summary, according to the union, the quantity and quality of learning during the school closure, for both the marginalized and the rich, were negligible. Some respondents, further, stated there had been reports of increasing incidences of girls being raped because they were left outside the care of the school, and sometimes, of their parents too.

On the expectations of the unions from the government in the context of the Covid-19 pandemic, varied responses were obtained. These were summarized as follows: (1) The government should pay serious attention to the disparities among learners which have been aggravated by the Covid-19 pandemic. They need to provide not only sufficient resources but also psychosocial support for the disadvantaged children. (2) Similarly, the teachers will require resources and psycho-social support to cope with the challenges of teaching and learning resulting from the pandemic. (3) The Covid-19 pandemic is a wake-up call for government to pay more attention to remote learning. Nevertheless, the teachers want all the benefits and values that the digital facilities can add to teaching and learning but never to be replaced by the computers and these other facilities. (4) The government should take teacher professional development seriously in order to build the capacity of teachers to cope with the shift to remote learning. (5) Above all, government must hold inclusivity as an absolute option where all learners 
are able to benefit from teaching and learning equally. (6) Government should improve the capacity of schools to cope with the challenges of the Covid-19 pandemic as the private schools are currently doing far better than the public schools in that regard.

\section{Discussion of Findings}

\subsection{Contributing to the On-Going Global Research on Covid-19 and Education}

Basically, this study is a follow-up of the earlier research conducted at the global level in March by Education International (2020b, 2020d). The report of that earlier survey asserted that the findings were "presented from a global perspective, which masks regional trends and differences that are significant in some cases" (Education International $2020 \mathrm{~d}$, p. 3). Therefore, the findings of this study fill this critical gap, and helped to have a more in-depth focus and understanding of the situation in Africa. Furthermore, in that earlier study, Africa contributed only $18(19.4 \%)$ of the 93 responses worldwide. The response rate is now improved upon by the 53 responses in the current study, which have enriched the African story.

Importantly, this study provided Education International Africa Region with some evidences of the situation in Africa, which it shared with the international community as part of the celebration of the World Teachers Day, October 5, 2020. The theme of the 2020 World Teachers Day, 'Teachers: Leading in crisis, reimagining the future,' lays emphasis on the role of teachers as professionals who should be trusted with leadership responsibility by the government and society at large in times of crisis in the education system, such as being experienced during the Covid-19 pandemic (UNESCO, 2020b). Thus, the findings of this study provided indicators, facts and figures that facilitated the meaningful discussions and debates on the World Teachers' Day about how teachers could play leadership role in times of emergency.

Furthermore, the report of this study corroborated the findings of the earlier research by Education International at the global level. For instance, the earlier report indicated that in most places, teaching and learning moved to online platforms but there was no significant support from governments to teachers to help them to teach online effectively. Similarly, the digital divide created two worlds of the privileged students on the one hand who continued learning via online modes, and on the other, vulnerable students - those with disabilities, economically poor family backgrounds, and dwellers of rural areas - unempowered to adequately take part in digital and distance learning (EI, 2020b).

In a related development, UNESCO, UNICEF, and World Bank (2020) instituted a global survey of the responses of the countries to the Covid-19 school closures. The research has been running online continuously from April 2020, and its growing database is condensed in MS Excel sheet which anyone anywhere in the world can download as an Open Education Resource. The findings of this study corroborated the findings of the UNESCO, UNICEF and World Bank research.

\subsection{Teaching and Learning During the Covid-19 Pandemic}

Prior to the Covid-19 pandemic, UNESCO (2015) had described the teaching profession as facing a process of 'deprofessionalization' denoted by the 'influx of unqualified teachers, casualization of teachers, reduction in professional autonomy, erosion of quality of the teaching profession, poor remuneration of teachers and the encroachment within educational institutions of private management techniques' (UNESCO, 2015, p. 54). Also, UNESCO Institute for Statistics (2016) estimated that in Sub-Saharan Africa, 70\% of the countries had acute shortages of teachers, and $90 \%$ had the shortages at the secondary education level. It then estimated that for the Sub-Saharan Africa to meet the SDG4 targets, additional 17 million (6.3 million for primary and 10.8 million for secondary education) are required. UNESCO (2017) further pointed to the growing number of out-of-school children and adolescents in countries affected by conflicts and natural disaster. Based on this, it called for "emergency preparedness and recovery and the development of international standards and legal mechanisms" (UNESCO, 2017, p. 15) and planning for disaster risk reduction and strategies for overcoming post-conflict challenges. It is obvious that the Covid-19 pandemic has worsened these challenges and caused a decline in the 'quantity and quality' of teaching and learning in Africa, as this study had revealed.

The finding that online teaching and learning in Africa were ineffective is also not surprising because data from the literature (e.g., African Union Commission, 2020a, 2020b; African Union Commission \& UNICEF, 2020; UNESCO, 2020a; UNESCO Institute for statistics, 2016; Teacher Task Force, 2020a, 2020b) reveal the numerous challenges in Africa which make the use of online approach difficulty and of limited impact. Some of the challenges are the dearth of digital infrastructure (absence of computers for individuals and homes, poor internet coverage especially for the rural areas), lack of electricity, poor ICT skills and a huge number of teachers who did not attain the required minimum professional competences. According to UNESCO Institute 
for Statistics (2016), even for teachers with the minimum teaching qualification, they have not been sufficiently trained in ICT or prepared for a total shift to online education at the scale warranted by the Covid-19 pandemic. Indeed, the respondents gave the same reasons highlighted in the literature as the reasons why the online approach did not work. In August 2020, the United Nations released what it termed 'Policy brief: Education during COVID-19 and beyond.' The United Nations Secretary-General, António Guterres, while launching the Brief warned that the Covid-19 pandemic 'has created the most severe disruption in the world's education systems in history and is threatening a loss of learning that may stretch beyond one generation of students'; and that the school closures could erase the decades of progress made in education (SDG-Education, 2030 Steering Committee Secretariat, 2020, p. 1). The Brief stated that the Covid-19 pandemic affected 1.6 billion learners in all the continents and over 190 countries. It also asserted that the "closures of schools and other learning spaces have impacted 94 per cent of the world's student population, up to 99 per cent in low and lower-middle income countries" (United Nations, 2020, p. 2). It opined that apart from worsening the disparities in educational opportunities existing before the pandemic, about 23.8 million children and youth may dropout from pre-primary to tertiary education levels.

Nevertheless, the African Union Commission strongly advocates a shift to online learning in the face of the pandemic. The framework it put forward for this purpose is called 'DOTSS' for short, which stands for Digital, Online, Teachers, Safety, and Skills (African Union Commission, 2020b). In a nutshell, the DOTSS framework advocates 'digital connectivity' of all schools; online learning including the use of radio, television, podcast, and other distance education modes; empowering teachers to facilitate and motivate online learning; ensuring the cyber safety of teachers and learners while online and offline; and focusing learning on 'skills development combining foundational, digital, 21st century, entrepreneurial and job specific skills' (AUC \& UNICEF, 2020, p. 1). Overall, other numerous international organizations in education, other than Education International and African Union Commission, showed interest and participated actively in finding ways to reduce the impact of the Covid-19 pandemic on the education system. Examples are the Africa Federation of Teaching Regulatory Authorities (AFTRA, 2020); Commonwealth Secretariat (2020); Education Development Trust (2020); Teacher Task Force and International Labour Organisation (2020a, 2020b); UNESCO International Research and Training Centre, UNESCO Institute for Information Technologies in Education and Smart Learning Institute, Beijing Normal University, China (2020); UNESCO, UNICEF and World Bank (2020); UNESCO, Teacher Task Force and ILO (2020); UNESCO International Institute for Capacity Building in Africa and Association for the Development of Education in Africa (2020); UNHCR (2020); UNICEF, WHO and IFRC (2020); World Bank Group (2020); and The World Bank Education Global Practice (2020). In May 2020, a document released by UNESCO, Teacher Task Force and ILO gave a summary of the key indices proffered by the various international organisations to support teachers, education support personnel and students when reopening schools. The indices covered (1) Social and policy dialogue; (2) Safety and physical health; (3) Psycho-social support; (4) Teaching and Learning; (5) Human \& financial resources; and (6) Monitoring and evaluation (UNESCO, Teacher Task Force \& ILO 2020). Individual scholars (e.g. Armand-Doucet, et al 2020) equally did extensive research that documented best practices on teaching and learning during the pandemic.

\subsection{Social and Policy Dialogue Between the Education Unions and Government}

Arising from the finding that several unions are either not consulted or sufficiently consulted by the government, it is important to refer again to the various guidelines (African Union, 2020a, 2020b; African Union \& UNICEF, 2020; Education International, 2020d, 2020e; Teacher Taskforce and ILO, 2020a, 2020b; etc.) which underscored the need for governments to work jointly with teachers and education support personnel, through their unions, in measures intended to address the impact of the Covid-19 pandemic on all aspects of education be it curriculum, school reopening, learning assessment, mode of teaching, health protocols and other issues. Social dialogue with the government is a right of the teachers and education support personnel which they can exercise through their unions. The non-consultation of the unions by any government may, therefore, pose danger to the health and safety of the students, teachers and education support personnel, and seriously undermine the quality of teaching and learning during and after the Covid-19 pandemic. Specifically, Education International called on the government to communicate "transparently and continuously about the plans for reopening onsite education and the extent to which they are informed by the advice of health experts" and reiterated that "continuous social and policy dialogue with educators and their unions is the cornerstone of any successful education strategy" (2020f, p. 1).

\subsection{Teacher Working Conditions}

The findings of this study regarding impact of the Covid-19 pandemic on the salaries and employment conditions of the teachers and education support personnel corroborate earlier findings by Education International. The earlier findings revealed that all categories of education personnel were affected by the impact 
of the Covid-19 pandemic in varying degrees. For instance, it showed that part-time teachers on temporary contracts $(47 \%)$ and those classified as "other" $(57 \%)$ were the most affected; however, the full-time teachers on temporary contracts $(27 \%)$ and education support personnel (31\%) were also significantly affected. The least affected in that earlier report were full time teachers on permanent contract $(8 \%)$ and part-time teachers on permanent contracts $(16 \%)$. This trend has persisted till the current study. The data from the current study showed that the education workers were affected in terms of loss of contract, delay or non-payment of salaries and in some cases reduced salaries as the employers struggled to cope with a dwindling financial base. The explanations from both the online questionnaire and interview indicated that teachers and education support personnel in the private sector were the worst affected. The private schools lost much revenue during the school closures and, therefore, had to lay off their workers, delay their salaries or pay only in part.

In the case of Covid-19 infections among teachers and students, the figures provided by few respondents and the remarks from those who did not, revealed that students and teachers had been infected. They pointed to a likely high risk of infection when schools reopen fully across the continent unless maximum efforts are made to adhering to the WHO protocol and guidelines for the reopening of schools advocated by the Education International and other international organisations. Perhaps, the latest information coming from the Ministry of Education in Nigeria underscores the fact that students and education workers are highly vulnerable to infection, and that the reopening of schools may create an upsurge in the number of Covid-19 infections. In a press interview on September 10, Nigeria's Minister of State for Education, Chukwuemeka Nwajiuba, announced the fear about the planned reopening of schools in the country from September 21, 2020. According to him, the data from the health authorities showed that $15 \%$ of the Covid-19 infections had come from the school environment (Silas 2020). These facts call for serious preparation to put in place the relevant health protocols while reopening the schools.

\subsection{Union Action}

The findings indicated that the unions dedicated their time to the sensitization of their members and social dialogue with government while to some extent, some unions also devoted time to developing educational tools, applications, portals, and other resources. On its part, the Education International Africa Region had participated actively in the actions and research undertaken by Education International at the global level from the inception of the Covid-19 pandemic. In addition, it took steps to ensure that the demands of the parent body are reinforced in Africa; and, that the education system, particularly the interests of the students, teachers and education support personnel are protected (Education International Africa Regional Committee, 2020a). These are in line with the actions expected of the unions during and after the Covid-19 pandemic.

\subsection{Reopening of the Educational Institutions}

The reopening of schools in Africa are taking place in phases and with 'cautious optimism' that the reopening of schools will not flare up the Covid-19 infections. The cautious optimism is in line with the WHO (2020) protocols and international guidelines issued by Education International (2020f) and other organisations (Teacher Taskforce \& ILO, 2020a, 2020b). These emphasize the need to prioritise the health and safety of students, teachers, and education support personnel in the reopening of schools. The findings also showed that the unions were evenly divided concerning the right time to reopen the schools. Roughly half of the unions supported the immediate resumption of schools while the other half preferred a future date when the pandemic must have come under control. This explains why, as confirmed by the interviews, some unions (e.g., NANTU, Namibia and SADTU, South Africa) reported cases of the government having to shift dates of school resumption due to opposition by the unions. It does seem, therefore, that many unions reluctantly accepted the reopening of schools now. Ultimately, the reopening of schools must accord priority to the health and safety of the students, teachers, and education support personnel. This is necessary especially as the findings showed that the Covid-19 protocols put in place for the reopened or reopening schools were rated as being average (that is, 3 ) on a scale of $1-5$. More work is required in this regard to ensure that the health and safety of the education workers and the learners are not put at risk.

Furthermore, the Teacher Task Force (2020a, pp. 5-6) Report revealed the varieties (possibly best practices) of responses to the COVID-19 pandemic by some countries in Africa and these could be applied by the rest of the African countries to strengthen the education system as the schools reopen. The Teacher Task Force classified these responses into seven as follows: (1) "Use of mixed ICT and media solutions" with examples as Benin, Burkina Faso, Cote d'Ivoire, Djibouti, Gambia, Rwanda, Senegal, South Africa and Uganda; (2) Reinforcing teacher capacity - example Burkina Faso, Gambia, Rwanda, Senegal, South Africa, and Uganda; (3) Psychosocial support-example Benin, Cote d'Ivoire, South Africa and Uganda; (4) Modifying 
assessment—example Benin and Senegal; (5) "Developing health protocols for reopening schools" —example Burkina Faso, Cote d'Ivoire, Senegal, and South Africa (6) Social dialogue-Gambia, Senegal, South Africa, and Uganda; and (7) Other responses.

\subsection{Fears and Expectations of the Unions Going Forward}

Most of the respondents expressed fear that educational technologies and online learning may lead to redundancy and loss of job by teachers and education support personnel. They also fear that it might lead to loss of the power of the teacher at the workplace, which will create a state of alienation, sociologically speaking. The Education International (n.d.) 'Protocol on the use of information and communications technology in education' raised these concerns also but asserted that 'new technology can never substitute for the relationship between teacher and student or teacher and class' (Education International, 2019, p. 1). It believes that educational technologies which it described as 'artificial intelligence (AI) software and super-fast computers, combined with sophisticated and highly capable robotics' - have great advantages such as the ability of the technologies to assist the teachers in the classroom, help create adaptive online courses and promote other virtual reality applications. However, it opined that they cannot take the place of the teachers. According to Education International, the teacher creates a socio-psychological environment which boosts learning, and educational technologies do not have such capacity. Furthermore, Education International (2020d) announced that it commissioned its Reference Group on the Future of the Teaching Profession to help to chart a new way forward. In that regard, the Group is working on a survey of Education International member organisations up to August 2020 and collaborating with the International Labour Organisation (ILO) to develop new policies on the future of work.

The study also discovered a pervasive fear among the respondents that the Covid-19 pandemic might exacerbate the educational inequality between the children from the rich and those from the poor homes. Earlier, Education International (2019) had expressed the same fear that online learning and the application of other digital educational technologies might worsen the 'digital divide' between the privileged and marginalized learners. If these fears materialize, then it may be difficult to achieve the African Union (2016) Continental Education Strategy for Africa (CESA, 2016-2025) or the United Nation's Sustainable Development Goal (SDG) 4 which calls for 'inclusive and equitable quality education' and 'lifelong learning opportunities for all (United Nations, 2015). Education International (2020b), therefore, called for effective and coherent policies from the international and regional organisations concerning Covid-19 and release of financial resources by the international financial institutions on liberal terms to fight Covid-19. It also called on the governments to mobilise people and resources at all levels and sectors towards halting the pandemic; and to provide support to the marginalized learners to ensure that they are not disadvantaged in tests and examinations due to the digital divide.

Regarding the expectations of the unions from the government going forward, in the context of the Covid-19 pandemic, they would want the government and stakeholders to institute measures to bridge the widening educational inequalities between the children from the poor and rich homes; prioritise the health of the students, teachers and education support personnel; enhance the capacity of teachers to engage in online education; provide digital and related infrastructure; and protect the pay and employment conditions of the teachers; and many other demands. Perhaps, it is important at this point to restate the advocacy of the Education International, which aligns with the six key areas adopted at the beginning of the pandemic by the Teacher Task Force (2020a). The advocacy called for the (1) preservation of employment and wages; (2) prioritization of the health, safety and well-being and teachers and learners; (3) inclusion of teachers while developing responses in the education sector to COVID-19; (4) provision of adequate professional support and training; (5) putting equity at the heart of education responses; and (6) inclusion of teachers in aid responses (Teacher Task Force, 2020b). Similarly, the Teacher Task Force and International Labour Organisation (2020a) issued guidance for policy makers on the kind of support required by teachers to go back to school. The seven thrusts of the support are: (1) Social dialogue and communication; (2) Safety and health; (3) Teachers' psychological and social-emotional well-being; (4) Teacher preparation and learning; (5) Deployment, teachers' rights and working conditions; (6) Financial resources and investments; and (7) Monitoring and evaluation. These are important frameworks for understanding the unions' expectations.

\section{Conclusion and Recommendations}

The teachers hold the key to quality education. Perhaps, they are the single most important factor for the achievement of the SDG4 which advocates 'inclusive and equitable quality education' for all. In other words, the achievement of the SDG4 is largely predicated on the competences, perception, motivation, and aspirations of the teachers and education support personnel. Therefore, their views must count as the world explores the best 
ways to address the unprecedented disruptions wrecked on the education system by the Covid-19 pandemic. This is the reason why this and other studies exploring the situation, views and proposals of the teachers and education support personnel are critical. This study has, therefore, filled important gaps in information regarding the impact of the pandemic on education in Africa and what the teachers and education support personnel are experiencing and expecting from the government and international stakeholders.

Based on the findings, the following recommendations are made.

\section{For Education International}

- To continue with the pooling of resources on the impact of the Covid-19 pandemic on education and sharing of the best practices among the unions.

- To call on the governments to provide adequate digital professional development for teachers and education support personnel.

- To collaborate with the governments and other international agencies to revise the existing international guidelines for managing teaching and learning in times of crisis, based on lessons learnt during the COVID-19 pandemic.

For African Union

- To incorporate the outcomes of this and other relevant studies in the African Union "DOTSS Framework" which advocates the digital connectivity of schools, online learning, training and motivation of teachers, safety online and offline, and skills focused learning.

For African Governments

- To comply with the protocols issued by the WHO and guidelines for school reopening issued by Education International, Teacher Task Force, UNESCO, ILO, and other relevant international authorities.

- To work with the education unions to address their fears and expectations elaborated in this study by tackling the challenges of the vulnerable and marginalized learners, professional development of teachers in online education, provision of digital infrastructure, and protection of the pay and employment conditions of teachers and education support personnel.

\section{Acknowledgements}

The work was commissioned and facilitated by the Education International African Regional Office based in Accra, Ghana with Dr. Dennis Sinyolo as the Chief Regional Coordinator. He was assisted by his officers Pedi Anawi, Regional Coordinator, and Victor Kpandja, Administrative Officer. Their collaboration and mobilization of the Education International member unions to respond to the instruments were of immense value. The various representatives of the unions, most of them being the President, Secretary General or other high-ranking official are highly appreciated for sparing their precious time to provide their views on the matters investigated. The various authorities cited in this report, which have been duly acknowledged in the references, contributed in no small measure to giving the survey a sound foundation.

\section{References}

Africa Centre for Disease Control. (2020). Coronavirus disease 2019 (COVID-19): Latest updates on the COVID-19 crisis from Africa CDC. Retrieved from https://africacdc.org/covid-19/

Africa Federation of Teaching Regulatory Authorities. (2020). Indo-Africa discussion: Sharing experiences on teachers during Covid-19. Abuja: AFTRA.

African Union Commission. (2016). Continental education strategy for Africa, 2016-2025. Addis Ababa: AUC.

African Union Commission. (2020a). Communique of the Bureau of the Specialized Technical Committee on Education Science and Technology of the African Union. Addis Ababa: AUC.

African Union Commission. (2020b). Equitable, quality and relevant education in Africa. Addis Ababa: AUC.

African Union Commission/UNICEF. (2020). Joint AUC/UNICEF statement to member states on response of the education sector to COVID-19 to ensure continuity of learning. Addis Ababa: AUC. Retrieved from https://edu-au.org/announcements-and-opportunities/au-statement-on-response-of-the-education-sector-to-c ovid-19

Armand-Doucet, A., D., Netolicky, K. T., \& Tuscano, F. J. (2020). Thinking about pedagogy in an unfolding pandemic: An independent report on approaches to distance learning during COVID19 school closures. 
Retrieved from https://issuu.com/educationinternational/docs/2020_research_covid-19_eng

Commonwealth Secretariat, London. (2020). COVID-19: Learning goes on. Retrieved from https://www.thecommonwealth-educationhub.net/

Education Development Trust. (2020). Report: Overview of emerging country level response to providing educational continuity under COVID-19-Best practice in pedagogy for remote teaching. Retrieved from http://www.edtechhub.org/coronavirus

Education International. (n.d.). International protocol on the use of information and communications technology in education. Brussels: E.I. Retrieved from https://spaces.hightail.com/space/Pj2OnCG65M

Education International. (2019). Resolution on: The future of the teaching profession. Retrieved from https://www.ei-ie.org/en/detail/16444/resolution-on-the-future-of-the-teaching-profession

Education International. (2020a). Guiding principles on the COVID-19 pandemic. Retrieved from https://www.ei-ie.org/en/detail/16701/guiding-principles-on-the-covid-19-pandemic

Education International. (2020b). Survey report on Covid-19 and education: How education unions are responding. Brussels: EI.

Education International. (2020c). Executive Board Resolution on EI's response to the Covid-19 pandemic. Retrieved from https://www.ei-ie.org/en/detail/16723/covid-19-educators-call-for-global-solidarity-and-a-human-centred-a pproach-to-the-crisis

Education International. (2020d). Covid-19 and education: How education unions are responding - Survey report. Brussels: EI. Retrieved from https://issuu.com/educationinternational/docs/2020_covid19_survey_report_eng_final

Education International. (2020e). Shaping the future of the teaching profession. Retrieved from https://www.ei-ie.org/en/detail/16865/shaping-the-future-of-the-teaching-profession

Education International. (2020f). EI guidance to reopening schools and education institutions. Brussels: EI. Retrieved from https://www.ei-ie.org/en/detail/16760/education-international-guidance-on-reopening-schools-and-educatio n-institutions

Education International. (2020g). Kenya: Union sues university leaders over cuts to salaries of academics. Retrieved from https://www.ei-ie.org/en/detail/16853/kenya-union-sues-university-leaders-over-cuts-to-salaries-of-academi cs

Education International. (2020h). Zimbabwe: Trade unions win court battle on school re-opening. Retrieved from https://www.ei-ie.org/en/detail/16841/zimbabwe-trade-unions-win-court-battle-on-school-re-opening

Education International Africa Regional Committee. (2020). Statement of COVID-19 impact and re-opening of schools.

https://www.ei-ie.org/en/detail/16762/ei-african-regional-committee-adopts-statement-of-covid-19-impact-a nd-re-opening-of-schools

SDG-Education 2030 Steering Committee Secretariat. (2020). Education during COVID-19 and beyond (UN Secretary General, August 2020). Paris: UNESCO Headquarters. Retrieved from https://www.sdg4education2030.org/education-during-covid-19-and-beyond-un-secretary-general-august-2 020

Silas, D. (2020). Nigerian government gives update on full reopening of schools. Daily Post, September 10. Retrieved from https://dailypost.ng/2020/09/10/nigerian-govt-gives-update-on-full-reopening-of-schools/

Teacher Task Force. (2020a). Report of the regional virtual meeting for sub-Saharan Africa: COVID-19 education crisis. Supporting teachers in distance learning and on school reopening held 28 May. Paris: UNESCO.

Teacher Task Force. (2020b). Response to the COVID-19 outbreak: Call for action on teachers. Paris: TTF. Retrieved

from https://teachertaskforce.org/knowledge-hub/response-covid-19-outbreak-call-action-teachers-0

Teacher Task Force, \& ILO. (2020a). Supporting teachers in back-to-school efforts guidance for policy-makers. 
Paris:

UNESCO.

Retrieved

from

https://unesdoc.unesco.org/ark:/48223/pf0000373479?fbclid=IwAR1AT--JAAOq51JrC9Oaf3ri3hhFhDf9yx c47pf-pQfvhwMXLQjdPR1nagc

Teacher Task Force, \& ILO. (2020b). Supporting teachers in back-to-school efforts: A toolkit for school leaders. Retrieved from https://teachertaskforce.org/sites/default/files/202006/TTF_BackToSchool_Toolkit\%20for\%20school\%20le aders.pdf

The World Bank Education Global Practice. (2020). Guidance note: Remote learning \& COVID-19. Retrieved from https://www.worldbank.org/en/topic/edutech

UNESCO. (2015). Rethinking education: Towards a global common goal? Paris: UNESCO.

UNESCO. (2017). Education transforms lives. Paris: UNESCO.

UNESCO. (2020a). Covid-19: A global crisis for teaching and learning. Paris: UNESCO.

UNESCO. (2020b). World Teachers' Day. Retrieved from https://en.unesco.org/commemorations/worldteachersday\#: :text=In\%202020\%2C\%20World\%20Teachers' $\% 20$ Day,crisis $\% 2 \mathrm{C} \% 20$ reimagining $\% 20$ the $\% 20$ future $\% \mathrm{E} 2 \% 80 \% 9 \mathrm{D}$.

UNESCO. (2020c). Covid-19 Education response, education sector Issue Notes No.7.1. Retrieved from https://reliefweb.int/report/world/unesco-covid-19-education-response-education-sector-issue-notes-issue-n ote-n-71-school

UNESCO Associated Schools Network. (2020). Covid-19-What do members of UNESCO Associated Schools say? Retrieved from https://aspnet.unesco.org/en-us/covid-19

UNESCO Institute for Statistics. (2016). The world needs almost 69 million new teachers to reach the 2030 education goals. UIS Fact Sheet, No. 39.

UNESCO International Institute for Capacity Building in Africa and Association for the Development of Education in Africa. (2020). Distance learning in Africa during COVID 19 school closure: African country experiences in the use of mixed media-ICT, TV, radio, mobile phones, print media and others. Addis Ababa: IICBA.

UNESCO International Research and Training Centre; UNESCO Institute for Information Technologies in Education; \& Smart Learning Institute, Beijing Normal University, China. (2020, March). Guidance on active learning at home during educational disruption: Promoting student's self-regulation skills in Covid-19 outbreak. Retrieved from https://iite.unesco.org/publications/guidance-on-active-learning-at-home-during-educational-disruption/

UNESCO \& Teacher Task Force \& ILO. (2020, May). Guidance for supporting teachers and other education staff when reopening schools. Paris: UNESCO. Retrieved from https://en.unesco.org/news/back-school-efforts-must-include-teachers

UNESCO, UNICEF, \& World Bank. (2020). Survey on national education responses to COVID-19 school closures. Retrieved from http://tcg.uis.unesco.org/survey-education-covid-school-closures/

UNICEF, WHO, \& IFRC. (2020). Key messages and actions for COVID-19 prevention and control in schools. Retrieved

from

https://www.who.int/docs/default-source/coronaviruse/key-messages-and-actions-for-covid-19-prevention-a nd-control-in-schools-march-2020.pdf?sfvrsn=baf81d52_4

UNHCR. (2020). Supporting continued access to education during Covid-19: Emerging promising practices. Retrieved from https://www.unhcr.org/5ea7eb134.pdf

United Nations. (2015). Transforming our world: The 2030 Agenda for sustainable development. New York. $\mathrm{UN}$.

United Nations. (2020). Policy brief: Education during COVID-19 and beyond. New York: UN. Retrieved from https://www.un.org/development/desa/dspd/wp-content/uploads/sites/22/2020/08/sg_policy_brief_covid-19 _and_education_august_2020.pdf

World Bank Group. (2020). The Covid-19 Pandemic: Shocks to education and policy responses. Retrieved from https://www.worldbank.org/en/topic/education/publication/the-covid19-pandemic-shocks-to-education-andpolicy-responses 
World Health Organisation. (2020). WHO Coronavirus Disease (COVID-19) dashboard. Journal of Rafsanjan University of Medical Sciences, 19(1), 1-2. https://doi.org/10.29252/jrums.19.1.1

\section{Copyrights}

Copyright for this article is retained by the author, with first publication rights granted to the journal.

This is an open-access article distributed under the terms and conditions of the Creative Commons Attribution license (http://creativecommons.org/licenses/by/4.0/). 